\author{
ANTIBACTERIAL ACTIVITY TEST OF EXTRACTS AND FRACTIONS OF ALGAE \\ Caulerpa racemosa FROM MANTEHAGE ISLAND WATERS OF NORTH MINAHASA \\ AGAINST THE GROWTH OF Escherichia coli AND Staphylococcus aureus BACTERIA
}

\title{
UJI AKTIVITAS ANTIBAKTERI EKSTRAK DAN FRAKSI ALGA Caulerpa racemosa DARI PERAIRAN PULAU MANTEHAGE MINAHASA UTARA TERHADAP PERTUMBUHAN BAKTERI Escherichia coli DAN Staphylococcus aureus
}

\author{
Yosefa E. H. Ritan ${ }^{1)}$, Defny S. Wewengkang1), Jainer P. Siampa ${ }^{1)}$ \\ ${ }^{1)}$ Program Studi Farmasi FMIPA UNSRAT Manado, 95115 \\ *etheldredaaritann26925@gmail.com
}

\begin{abstract}
Algae Caulerpa racemosa are able to produce chemical content that leave the potential to be antibacterial. The purpose of this study was to determine whether the extracts and fractions of algae Caulerpa racemosa had antibacterial activity against the Gram-negative bacteria Escherichia coli and the Gram-positive bacteria Staphylococcus aureus. The sample was extracted using the maceration method with 95\% ethanol and the fractionation method used was liquid-liquid fractionation. Antibacterial activity testing was carried out using the disc diffusion agar method. The results obtained from the antibacterial activity test on Escherichia coli bacteria produce an inhibition zone in all extracts and fractions used while Staphylococcus aureus bacteria produced an inhibition zone for all extracts and fractions, in ethanol extract with inhibitory value $6.72 \mathrm{~mm}$, $n$-hexane fraction $7.53 \mathrm{~mm}$, chloroform fraction $6.93 \mathrm{~mm}$ and fraction methanol $7.32 \mathrm{~mm}$, respectively. The extracts and fractions of algae Caulerpa racemosa samples showed no activity against Escherichia coli, while Staphylococcus aureus has performed antibacterial activity with moderate category. The conclusion of this study, extracts and fractions of algae caulerpa racemosa had no antibacterial activity on the bacteria Escherichia coli while bacteria Staphylococcus aureus had antibacterial activity with moderate inhibition.
\end{abstract}

Keywords: Algae Caulerpa racemosa, Antibacterial, Escherichia coli, Staphylococcus aureus.

\begin{abstract}
ABSTRAK
Alga Caulerpa racemosa mampu menghasilkan kandungan kimia yang berpotensi sebagai antibakteri. Tujuan dari penelitian ini yaitu untuk mengetahui aktivitas antibakteri ekstrak dan fraksi dari alga Caulerpa racemosa di Perairan Pulau Mantehage Minahasa Utara terhadap bakteri Escherichia coli sebagai bakteri Gram-negatif dan Staphylococcus aureus sebagai bakteri Gram-positif. Sampel diekstraksi dengan menggunakan metode maserasi dengan pelarut etanol $95 \%$ dan metode fraksinasi yang digunakan yaitu fraksinasi cair-cair. Pengujian aktivitas antibakteri yang dilakukan menggunakan metode difusi agar. Hasil yang didapat dari uji aktivitas antibakteri pada bakteri Escherichia coli tidak menghasilkan zona hambat pada semua ekstrak dan fraksi yang digunakan sedangkan pada bakteri Staphylococcus aureus menghasilkan zona hambat pada semua ekstrak dan fraksi yaitu, ekstrak etanol dengan daya hambat 6,72mm, fraksi n-heksan 7,53mm, fraksi kloroform 6,93mm dan fraksi metanol 7,32mm. Kesimpulan dari penelitian ini, ekstrak dan fraksi dari sampel alga Caulerpa racemosa tidak memiliki aktivitas pada bakteri Escherichia coli sedangkan pada bakteri Staphylococcus aureus memiliki aktivitas antibakteri dengan daya hambat yang sedang.
\end{abstract}

Kata Kunci: Alga Caulerpa racemosa, Antibakteri, Escherichia coli, staphylococcus aureus 


\section{PENDAHULUAN}

Alga hijau seperti Caulerpa racemosa merupakan salah satu jenis alga hijau yang hidup menyebar dibeberapa perairan di Indonesia. Alga Caulerpa racemosa memiliki ciri - ciri seperti thallus yang berwarna hijau seperti tanaman rumput, terdiri dari banyak cabang tegak dan pada puncak cabang terdapat bulatan-bulatan seperti anggur (Yudasmara, 2014). Alga Caulerpa racemosa telah diketahui memiliki aktivitas antibakteri dilihat dari uji yang telah dilakukan dimana terdapat tanda spektrum luas terhadap bakteri patogen Gram-negatif dan Gram-positif yang diuji dengan zona hambat 12-16 mm (Kandhasamy dan Arunachalam, 2008).

Infeksi yang disebabkan oleh bakteri dapat diobati dengan antibakteri. Escherichia coli dan Staphylococcus aureus merupakan contoh dari bakteri yang dapat menyebabkan infeksi pada manusia. Bakteri Staphylococcus aureus biasanya ditemukan di hidung, tenggorokan dan lapisan luar epidermis. Staphylococcus aureus merupakan bakteri Gram-positif berbentuk bulat dan tumbuh pada suhu optimum $37^{\circ} \mathrm{C}$ (Wulandari, 2017). Infeksi yang menyebabkan kerusakan pada kulit atau luka yang terdapat pada organ tubuh dapat terjadi ketika bakteri Staphylococcus aureus mengalahkan mekanisme pertahanan tubuh. Ketika bakteri Staphylococcus aureus masuk ke peredaran darah bakteri ini dapat menyebar ke organ lain dan menyebabkan infeksi (Melki dkk., 2012).

Bakteri Escherichia coli merupakan bakteri normal pada usus namun bakteri ini dapat bersifat patogen jika dalam keadaan tidak normal. Bakteri Escherichia coli pada keadaan tidak normal dapat menyebabkan beberapa penyakit seperti diare, infeksi saluran kemih, pneumonia (radang paru-paru), infeksi luka terutama di dalam abdomen dan meningitis atau biasa dikenal dengan radang selaput otak (Dima dkk., 2016).

Berdasarkan uraian diatas, maka peneliti tertarik untuk melakukan pengujian aktivitas antibakteri dari alga Caulerpa racemosa yang diambil dari perairan Pulau Mantehage pada bakteri Escherichia coli dan bakteri Staphylococcus aureus.

\section{METODOLOGI PENELITIAN}

\section{Bentuk, Waktu dan Tempat Penelitian Bentuk Penelitian}

Penelitian ini berbentuk eksperimen laboratorium yang dilakukan dengan cara menguji komponen yang diekstrak dari alga Caulerpa racemosa sebagai antibakteri pada Escherichia coli dan Staphylococcus aureus.

\section{Waktu dan Tempat Penelitian}

Penelitian ini dilaksanakan pada bulan Oktober 2020 sampai Maret 2021 di Program Studi Farmasi Fakultas Matematika dan Ilmu Pengetahuan Alam dan di Laboratorium Hama dan Penyakit Tumbuhan Fakultas Pertanian Universitas Sam Ratulangi.

\section{Alat dan Bahan}

Alat

Alat yang digunakan dalam penelitian ini yaitu masker, sarung tangan, gunting, botol $600 \mathrm{ml}$, talenan, cool box, pisau, Erlenmeyer (Pyrex), corong, rotary evaporator, timbangan analitik, corong pisah, gelas ukur, gelas kimia (Pyrex), cawan petri, autoklaf, pinset, pembakar spritus, magnetic stirrer, pipet tetes, micro tubes, hot plate, vortex, batang pengaduk, Laminar air flow, rak tabung reaksi, tabung reaksi, lemari pendingin, 906ethano1906, mikropipet, mistar berskala.

\section{Bahan}

Bahan-bahan yang digunakan yaitu alga Caulerpa racemosa, bakteri uji Escherichia coli dan Staphylococcus aureus, etanol, akuades, metanol, n-heksan, kloroform, pepton, natrium klorida, ekstrak daging (meat extract), agar, kloramfenikol paper disc, kertas cakram (paper disc), tissue, aluminium foil, kertas saring.

\section{Pengambilan Sampel}

Sampel alga Caulerpa racemosa diambil dari perairan Pulau Mantehage menggunakan alat bantu (masker, snorkel, fins dan tabung oksigen). Sampel yang diperoleh dimasukkan ke dalam zipper lock bag dan diletakkan di dalam cool box, kemudian langsung dibawa ke Laboratorium Farmakognosi dan Fitokimia, Program Studi Farmasi Universitas Sam Ratulangi. Sampel difoto dan diberi label serta nomor sampel, untuk selanjutnya dideterminasi.

\section{Ekstraksi Sampel}

Ekstrak alga Caulerpa racemosa dibuat dengan cara maserasi. Sampel dibersihkan dan dipotong kecil-kecil dimasukkan ke dalam botol $600 \mathrm{ml}$, kemudian direndam dengan pelarut etanol sampai sampel terendam semuanya dan dibiarkan selama 24 
jam. Sampel yang direndam disaring menggunakan kertas saring menghasilkan filtrat 1 dan debris 1 . Debris 1 kemudian diremaserasi dengan pelarut etanol sampai terendam semuanya dan dibiarkan selama 24 jam, sampel tersebut disaring menggunakan kertas saring menghasilkan filtrat 2 dan debris 2. Debris 2 kemudian diremaserasi dengan pelarut etanol sampai terendam semuanya dan dibiarkan selama 24 jam, sampel tersebut disaring menggunakan kertas saring menghasilkan filtrat 3 dan debris 3 . Filtrat 1,2, dan 3 dicampur menjadi satu kemudian disaring, lalu dievaporasi menggunakan rotary evaporator pada suhu $40{ }^{\circ} \mathrm{C}$ hingga kering dan selanjutnya ditimbang menggunakan timbangan analitik. Selanjutnya ekstrak kasar alga Caulerpa racemosa digunakan dalam fraksinasi dan pengujian antibakteri (Silap dkk, 2020).

\section{Fraksinasi Sampel}

Ekstrak kasar alga Caulerpa racemosa yang diperoleh dimasukkan ke dalam erlenmeyer, kemudian dilarutkan dengan metanol $80 \%$ sebanyak $100 \mathrm{~mL}$. Setelah larut, dimasukkan ke dalam corong pisah dan ditambahkan pelarut n-heksan sebanyak 100 $\mathrm{mL}$ setelah itu dikocok dalam corong pisah sampai homogen. Dibiarkan sampai terbentuk lapisan metanol dan lapisan n-heksan, kemudian masing-masing lapisan ditampung dalam wadah yang berbeda. Lapisan n-heksan kemudian dievaporasi menggunakan rotary evaporator hingga kering, lalu ditimbang dan diperoleh fraksi n-heksan. Selanjutnya, lapisan metanol ditambahkan akuades sebanyak 100 $\mathrm{mL}$ kemudian dipartisi dengan pelarut kloroform dengan perbandingan 1:1 v/v dalam corong pisah, setelah itu dikocok kembali sampai homogen. Dibiarkan sampai tebentuk dua lapisan yaitu lapisan metanol dan kloroform, kemudian masing-masing lapisan ditampung dalam wadah yang berbeda. Lapisan kloroform selanjutnya dievaporasi menggunakan rotary evaporator hingga kering lalu ditimbang berat sampel dan diperoleh fraksi kloroform. Lapisan metanol kemudian dievaporasi menggunakan rotary evaporator hingga kering, lalu ditimbang dan diperoleh fraksi metanol. Ketiga fraksi yang diperoleh akan digunakan dalam pengujian antibakteri. Rendemen-rendemen fraksi dihitung berdasarkan persamaan sebagai berikut:

$$
\text { Rendemen }=\frac{\text { Berat hasil ektrak }}{\text { Berat ektrak awal }} \times 100 \%
$$

\section{Sterilisasi Alat}

Alat-alat yang digunakan dalam penelitian aktivitas antibakteri ini disterilkan terlebih dahulu. Alat-alat gelas disterilkan dengan autoklaf pada suhu $121^{\circ} \mathrm{C}$ selama 15 menit, pinset dibakar dengan pembakaran di atas api langsung dan media disterilkan di autoklaf pada suhu $121^{\circ} \mathrm{C}$ selama 15 menit (Ortez,2005).

\section{Pembuatan media cair B1}

Pepton 0,5 g, ekstrak daging (meat extract) $0,3 \mathrm{~g}$, natrium klorida $0,3 \mathrm{~g}$, dan aquades sebanyak $100 \mathrm{~mL}$ diaduk sampai rata kemudian dibuat homogen menggunakan magnetic stirrer lalu diautoklaf pada suhu 121 ${ }^{\circ} \mathrm{C}$ selama 15 menit, ukur $\mathrm{pH}$ dengan menggunakan kertas $\mathrm{pH}$. Dipipet $1 \mathrm{~mL}$ media cair B1, kemudian masukkan dalam tabung reaksi dan tutup dengan aluminium foil. Media cair B1 siap digunakan sebagai media kultur bakteri (Ortez, 2005)

\section{Kultur Bakteri}

Media cair B1 yang sudah disiapkan sebelumnya, ditambahkan dengan masingmasing bakteri yang sudah dikultur (Escherichia coli dan Staphylococcus aureus) dipipet sebanyak $100 \mu \mathrm{L}$ kedalam tabung reaksi yang berbeda. Tutup dengan aluminium foil tiap tabung reaksi dan dimasukkan kedalam inkubator selama $1 \times 24$ jam pada suhu $37{ }^{\circ} \mathrm{C}$ (Silap dkk, 2020).

\section{Pembuatan Kontrol Positif dan Kontrol Negatif}

Kontrol positif dalam pengujian antibakteri ini menggunakan kloramfenikol paper disc. Kontrol negatif yang digunakan dalam penelitian ini yaitu menggunakan pelarut metanol, dengan cara membuat larutan stok metanol dengan mengambil sebanyak 200 $\mu \mathrm{L}$ metanol kemudian ditotolkan pada kertas cakram (Silap dkk, 2020).

\section{Pembuatan Larutan Uji}

Larutan uji dibuat dengan cara $2 \mathrm{mg}$ ekstrak kasar alga Caulerpa racemosa kemudian dilarutkan dalam $400 \mu \mathrm{L}$ metanol sehingga menghasilkan konsentrasi larutan uji sebesar $250 \mu \mathrm{g} / 50 \mu \mathrm{L}$. Perlakuan yang sama dilakukan pada fraksi n-heksan, fraksi kloroform dan fraksi metanol (Ortez, 2005). 


\section{Pembuatan Media Agar B1}

Pepton 0,5 g, ekstrak daging (meat extract) $0,3 \mathrm{~g}$, natrium klorida $0,3 \mathrm{~g}$, agar $1,5 \mathrm{~g}$ dan aquades sebanyak $100 \mathrm{~mL}$ diaduk sampai rata kemudian dibuat homogen menggunakan magnetic stirrer lalu diautoklaf pada suhu 121 ${ }^{\circ} \mathrm{C}$ selama 15 menit. Lakukan pengujian $\mathrm{pH}$ dengan kertas $\mathrm{pH}$. Media agar B1 siap digunakan untuk uji aktivitas antibakteri (Silap dkk, 2020).

\section{Pengujian Aktivitas Antibakteri}

Metode yang digunakan dalam penelitian ini yaitu metode difusi agar (disc diffusion Kirby and Bauer). Pada pengujian aktivitas antibakteri ini, cakram (paper disc) yang digunakan berukuran $6 \mathrm{~mm}$ dengan daya serap $50 \mu \mathrm{L}$ tiap cakram. Sampel yang telah ditentukan kosentrasinya $250 \quad \mu \mathrm{g} / 50 \quad \mu \mathrm{L}$ ditotolkan pada masing-masing cakram dengan menggunakan mikropipet. Untuk media agar B1 yang sudah diautoklaf pada suhu $121{ }^{\circ} \mathrm{C}$ selama 15 menit, kemudian dinginkan sampai suhu $40{ }^{\circ} \mathrm{C}$. Tuangkan media agar B1 ke cawan petri, ambil sebanyak $100 \mu \mathrm{L}$ bakteri yang telah di kultur dalam tabung reaksi, dipipet dan diinokulasi pada media agar B1 dan tunggu sampai media agar B1 mengeras. Masingmasing cawan petri diberi label dan nomor sampel yang sesuai. Letakkan kertas cakram yang telah ditotolkan sampel uji alga Caulerpa racemosa dengan pinset kedalam cawan petri lalu diinkubasi selama 1x24 jam (Ortez, 2005).

\section{Pengamatan dan Pengukuran Diameter Zona Bening}

Pengamatan dilakukan setelah 24 jam masa inkubasi. Daerah pada sekitaran cakram menunjukkan kepekaan bakteri terhadap antibiotik atau bahan antibakteri yang digunakan sebagai bahan uji yang dinyatakan dengan diameter zona bening yang terbentuk. Diameter zona bening diukur menggunakkan mistar berskala dengan cara diukur diameter zona bening horizontal ditambahkan dengan diameter zona bening vertikal lalu dibagi dua. Diameter $\leq 5 \mathrm{~mm}$ memiliki kekuatan daya hambat lemah, 6-10 $\mathrm{mm}$ daya hambat sedang, $11-20 \mathrm{~mm}$ daya hambat kuat dan $\geq 21 \mathrm{~mm}$ daya hambat sangat kuat (Susanto dkk, 2012).

\section{HASIL DAN PEMBAHASAN}

\section{Determinasi Sampel}

Determinasi alga Caulerpa racemosa dilaksanakan di Program Studi Farmasi Fakultas Matematika dan Ilmu Pengetahuan Alam Universitas Sam Ratulangi Manado. Determinasi sampel dilakukan untuk mengetahui apakah sampel yang diambil dan dilakukan pengujian aktivitas antibakteri adalah sampel yang sesuai.

\section{Ekstraksi dan Fraksinasi Sampel}

Sampel alga Caulerpa racemosa yang diambil dari pulau Mantehage, Minahasa Utara diekstraksi menggunakan metode maserasi. Ekstraksi menggunakan metode maserasi dikarenakan pengerjaannya mudah dan tidak menggunakan panas sehingga kandungan kimia pada sampel yang tidak tahan akan panas tidak rusak. Pada proses maserasi kandungan kimia pada sampel dapat ditarik oleh pelarut dikarenakan adanya perbedaan konsentrasi di dalam dan di luar sel, sehingga menyebabkan dinding sel sampel pecah karena tidak dapat menahan tekanan dari perbedaan konsentari (Restiana, 2018).

Ekstraksi alga Caulerpa racemosa metode maserasi dengan pelarut etanol $95 \%$ dikarenakan pelarut etanol dengan konsentrasi 95\% merupakan konsentrasi tinggi yang dapat menarik kandungan kimia pada sampel dengan baik dan pelarut etanol juga bersifat toksiksitas rendah, sehingga kandungan kimia pada sampel tidak rusak. Maserasi dilakukan selama 3 x 24 jam dengan pelarut yang sama. Pengulangan maserasi atau remaserasi pada sampel bertujuan untuk memaksimalkan penarikan kandungan kimia pada sampel oleh pelarut yang digunakan (Mujipradana dkk, 2018). Setelah didapatkan filtrat dari hasil maserasi, filtrat tersebut dievaporasi sehingga menghasilkan ekstrak kasar. Penggunaan evaporator bertujuan untuk menarik pelarut pada hasil maserasi dengan suhu 40 derajat $C$, karena suhu yang digunakan harus di bawah titik didih pelarut sehingga tidak merusak kandungan kimia pada sampel saat proses evaporasi.

Hasil ekstrak kasar yang diperoleh dari proses evaporasi, selanjutnya digunakan ke tahap fraksinasi. Proses fraksinasi bertujuan untuk memisahkan kandungan kimia dari sampel sesuai dengan tingkat kepolarannya. Metode fraksinasi yang digunakan yaitu fraksinasi cair-cair dimana disesuaikan dengan perbedaan tingkat kepolaran dari tiap-tiap 
PHARMACON- PROGRAM STUDI FARMASI, FMIPA, UNIVERSITAS SAM RATULANGI,

Volume 10 Nomor 2 Mei 2021

pelarut. Pelarut yang digunakan yaitu pelarut metanol sebagai pelarut polar, pelarut n-heksan sebagai pelarut non polar dan pelarut kloroform sebagai pelarut semi polar. Pada proses fraksinasi, pengocokan dilakukan karena dapat memaksimalkan dan membantu penarikan dari setiap pelarut terhadap kandungan kimia yang ada pada sampel. Pada proses fraksinasi akan terbentuk 2 lapisan dimana merupakan pemisah antara pelarut-pelarut yang digunakan dan juga dapat membantu dalam memisahkan pelarut satu dengan yang lainnya setelah proses fraksinasi. Pelarut dengan massa jenis yang lebih besar akan berada dibagian bawah, sedangkan pelarut dengan massa jenis kecil akan berada dibagian atas. Hasil fraksinasi yang diperoleh dari ketiga pelarut tersebut kemudian di evaporasi lagi sehingga menghasilkan ekstrak kasar masing-masing yang akan digunakan dalam uji aktivitas antibakteri. Hasil ekstrak dari fraksinasi yang di evaporasi dapat dilihat pada Tabel 1.

Tabel 1. Rendemen ekstrak dan fraksi alga Caulerpa racemosa

\begin{tabular}{ccccc}
\hline No & Sampel & Berat $(\mathbf{g})$ & Rendemen $(\%)$ & Warna \\
\hline 1 & Ekstrak Etanol & 9,64 & 6,88 & Coklat pekat \\
\hline 2 & Fraksi n-Heksan & 0,45 & 9,00 & Hijau Tua \\
\hline 3 & Fraksi Kloroform & 0,31 & 6,20 & Coklat muda \\
\hline 4 & Fraksi Metanol & 3,01 & 60,20 & Coklat muda \\
\hline
\end{tabular}

Jumlah ekstrak kasar memiliki bobot atau berat yang berbeda dikarenakan penggunaan pelarut yang tingkat kepolarannya berbeda, sehingga kandungan kimia yang tertarik dalam proses fraksinasi tertarik sesuai tingkat kepolarannya

\section{Uji Antibakteri}

Pengujian aktivitas antibakteri menggunakan bakteri Escherichia coli sebagai bakteri Gram-negatif dan bakteri Staphylococcus aureus sebagai bakteri Grampositif, hal ini dikarenakan untuk melihat aktivitas antibakteri dari sampel alga Caulerpa racemosa dari kedua jenis gram bakteri. Metode yang digunakan dalam pengujian ini yaitu metode difusi agar. Pemilihan menggunakan metode difusi agar dikarenakan metode ini mudah dilakukan dan peralatannya mudah didapatkan. Pengujian aktivitas antibakteri bertujuan untuk melihat apakah sampel alga Caulepra racemosa dengan suatu konsentrasi yang dipakai memiliki aktivitas antibakteri untuk kedua baketri uji yang dipakai (Eda, 2020). Aktivitas antibakteri dari sampel dapat dilihat dari zona hambat yang akan terbentuk disekitar cakram.
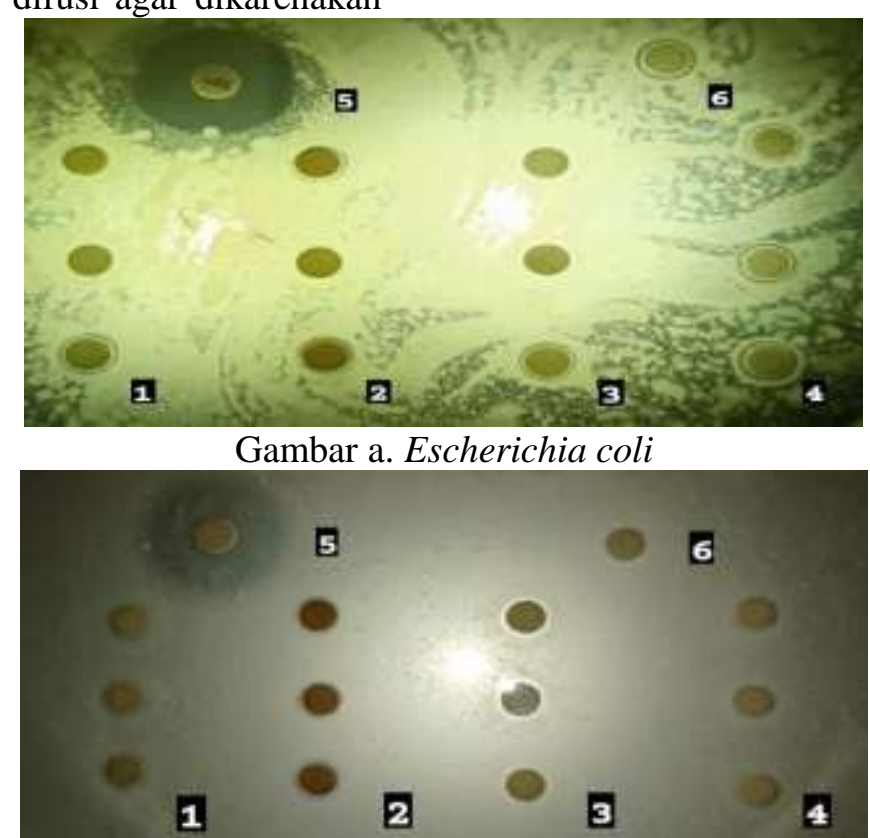

Gambar b. Staphylococcus aureus

Gambar 1. Hasil Uji Aktivitas Antibakteri dari Ekstrak dan Fraksi Alga Caulerpa racemosa: (a) Escherichia coli, (b) Staphylococcus aureus. Ket: (1) Ekstrak Etanol, (2) Fraksi 
Volume 10 Nomor 2 Mei 2021

Kloroform, (3) Fraksi n-Heksan, (4) Fraksi Metanol, (5) Kontrol Positif, (6) Kontrol Negatif.

Hasil pengukuran diameter dan ratarata diameter pengamatan daya antibakteri dari sampel alga Caulerpa racemosa yang dibagi menjadi ekstrak etanol, fraksi n-heksan, fraksi

kloroform dan fraksi metanol terhadap bakteri Escherichia coli dan Syaphylococcus aureus ditunjukkan pada Tabel 2.

Tabel 2. Hasil pengukuran diameter zona hambat ekstrak dan fraksi alga Caulerpa racemosa terhadap Escherichia coli dan Staphylococcus aureus.

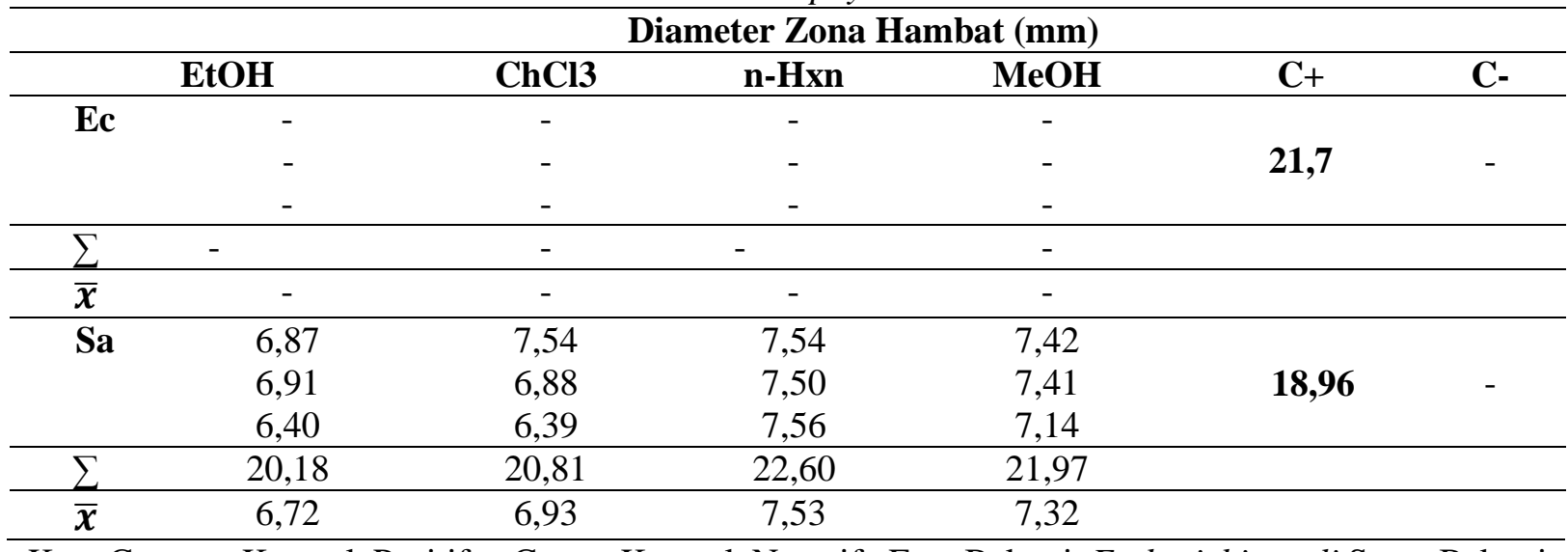

Ket: C+ $=$ Kontrol Positif, $\mathrm{C}-=$ Kontrol Negatif, Ec $=$ Bakteri Escherichia coli,Sa $=$ Bakteri Staphylococcus aureus, $\mathrm{mm}=$ milimeter, $\sum=$ Jumlah total, $\bar{x}=$ rata-rata

Pengamatan pada pengujian antibakteri ini dilakukan setelah diinkubasi selama 1 x 24 jam. Kontrol positif yang digunakan yaitu antibiotik kloramfenikol yang dimana telah diketahui memiliki spektrum luas terhadap bakteri Gram-positif dan negatif, sedangkan kontrol negatif yang digunakan adalah larutan metanol. Penggunaan kontrol negatif dan kontrol positif dalam pengujian antibakteri ini bertujuan untuk membandingkan zona hambat yang terbentuk selama pengujian.

Ekstrak dan fraksi dari alga Caulerpa racemosa tidak menunjukan aktivitas terhadap bakteri Gram-negatif Escherichia coli. Sedangkan pada pengujian aktivitas antibakteri Staphylococcus aureus terdapat zona hambat di sekitaran cakram sebesar $7,32 \mathrm{~mm}$ pada fraksi metanol, 7,53 mm pada fraksi n-heksan, 6,93 $\mathrm{mm}$ pada fraksi kloroform dan $6,72 \mathrm{~mm}$ pada ekstrak etanol. Hasil zona hambat dari tiap ekstrak dan fraksi dikategorikan daya hambat sampel alga Caulerpa racemosa pada bakteri Staphylococcus aureus sedang.

Dari hasil pengamatan dan pengukuran aktivitas antibakteri diketahui bahwa sampel alga Caulerpa racemosa memiliki aktivitas antibakteri pada bakteri Staphylococcus aureus didukung oleh penelitian yang dilakukan Wulandari (2017) yang berjudul Uji Aktivitas Antibakteri Ekstrak Kasar Caulerpa racemosa dengan Pelarut dan Bagian Alga yang Berbeda Terhadap Pertumbuhan Escherichia coli dan Staphylococcus aureus, sampel dari alga
Caulerpa racemosa memiliki aktivitas antibakteri pada bakteri Staphylococcus aureus. Sedangkan pada bakteri Escherichia coli tidak memiliki aktivitas antibakteri, dikarenakan perbedaan struktur sel pada kedua bakteri ini. Bakteri Escherchia coli mempunyai dinding sel dengan kandungan lemak yang tinggi dan struktur dinding sel yang berlapis sedangkan bakteri Staphylococcus aureus mempunyai struktur

\section{KESIMPULAN}

Berdasarkan hasil penelitian yang telah dilakukan pada ekstrak dan fraksi alga Caulerpa racemosa dari Perairan Pulau Mantehage Minahasa Utara memiliki aktivitas antibakteri terhadap bakteri Staphylococcus aureus dengan kategori sedang, tetapi tidak memiliki aktivitas antibakteri terhadap bakteri Escherichia coli.

\section{SARAN}

Berdasarkan hasil dan pembahasan aktivitas antibakteri ekstrak dan fraksi alga Caulerpa racemosa, maka disarankan dilakukan penelitian lanjut terhadap alga Caulerpa racemosa dengan metode pengujian yang lainnya.

\section{DAFTAR PUSTAKA}

Dima,L.L.R.H, dkk. 2016. Uji Aktivitas Antibakteri Ekstrak Daun Kelor (Moringa oleifera L.) Terhadap 
PHARMACON- PROGRAM STUDI FARMASI, FMIPA, UNIVERSITAS SAM RATULANGI,

Volume 10 Nomor 2 Mei 2021

Bakteri Escherichia coli dan Staphylococcus aureus. Program Studi Farmasi FMIPA Universitas Sam Ratulangi: Manado.

Eda, M, I, A. 2020. Uji Aktivitas Antimikroba Ekstrak dan Fraksi Karang Lunak (Sarcophyton sp.) Dari Perairan Pulau Bangka Likupang Terhadap Pertumbuhan Mikroba Staphylococcus aureus, Salmonella thypimurium dan Candida albicas. FMIPA Universitas Sam Ratulangi: Manado

Melki., Ayu, E. P. W., dan Kurniati. 2012. Uji Antibakteri Ekstrak Gracilaria $s p$ (Rumput Laut) Terhadap Bakteri Escherichia coli dan Staphylococcus aureus. Fakultas Matematika dan Ilmu Pengetahuan Alam. Universitas Sriwijaya: Indralaya.

Mpila, D. A. 2012. Uji Aktivitas Antibakteri Ekstrak Etanol Daun Mayana (Coleus atropurpureus benth) Terhadap Staphylococcus aureus, Escherichia coli dan Pseudomas aeruginosa Secara Invitro. Program Studi Farmasi FMIPA Universitas Sam Ratulangi: Manado.

Ortez, J, H. 2005. Disk Diffusion testing in manual of antimicrobial susceptibility testing. American society for Microbiology.

Restiana, F.R.2018. Pengaruh Lama Maserasi Terhadap Kadar Genistein Pada Ekstraksi Tempe. [Skripsi]. Program Studi Farmasi Universitas Sanata Dharma: Yogyakarta.

Silap, dkk. 2020. Uji Aktivitas Antimikroba Karang Lunak Dendronephtya Sp., Yang Dikoleksi Dari Desa Tumbak Kecamatan Pusomaen, Kabupaten Minahasa Tenggara Terhadap Escherichia Coli, Staphylococcus Aureus, Dan Candida Albicans. Jurnal Pharmacon UNSRAT. Vol. 9 (1).
Susanto, D., Sudrajat dan R. Ruga. 2012. Studi

Kandungan Bahan Aktif

Tumbuhan Meranti Merah (Shorea leprosula Miq) Sebagai Sumber Senyawa Antibakteri. 11 (2): 181-190.

Wulandari, Z. 2017. Uji Aktivitas Antibakteri Ekstrak Kasar Caulerpa Racemosa Dengan Pelarut Dan Bagian Alga yang Berbeda Terhadap Pertumbuhan Escherichia Coli dan Staphylococcus Aureus. [Skripsi]. Universitas Brawijaya: Malang.

Yudasmara, G, A. 2014. Budidaya Anggur Laut (Caulerpa Racemosa) Melalui Media Tanaman Rigid Quadrant Nets Berbahan Bambu. Jurnal Sains dan Teknologi Vol.3 No.2. 